\title{
Geocenter Møns Klint - et besøg vard
}

\section{Af GeologiskNyts webmaster, Steen Laursen}

Møns Klint er blevet udstyret med et yderst diskret geocenter til et yderst indiskret millionbeløb, og det er der kommet et enestående oplevelsescenter ud af. Her handler det om at hænge Møns klint og natur op på mikrosmå kokkolitter og tons tunge kalkskred.

Efter mange års arbejde med at samle penge og få tilladelser kunne Geocenter Møns Klint endelig åbne dørene for Dronning Margrethe, og GeologiskNyt sendte kort efter to børnefamilier igennem centret. Det var en stor succes.

\section{Monster om hjørnet}

Indgangen til centret er en smal betonkorridor, og alle forventninger er spændt til bristepunktet, for der er en verden af lyde nede for enden og en film med en grovædende mosasaurus i hovedrollen. Spændingen bliver fuldt tilfredsstillet, for lige om lidt løber vi ind i det gigantiske mosasaurushovede og tænder. Man ser den først, når man er lige foran.

Resten af mosasaurusen hænger over den geologiske del af centret og repræsenterer det helt store i kalken. Lige under dens hoved står der til gengæld en statue af en kokkolit i tre stadier: Hel, delvist ødelagt og endelig som en stak underkopper på gulvet. Statuen er nogle tusinde gange forstørret i forhold til originalen, som jo er mikroskopisk.

Interaktiv geologi med ledninger og trisser Fladskærmene på væggene er forventelige, og de reagerer selvfølgelig på tryk, men de gør det enkelt og informativt, du bestemmer selv farten, og der er godt nok ikke ret meget tekst. Alt, hvad der kan fortælles med grafik, er fortalt med grafik, så kun det allermest uhåndterlige er beskrevet med tekst. Den velsignelse hviler over hele centret.

Oven i købet er centret interaktivt med mere end skærme og overbevisende grafik. I et af lokalerne er loftet broderet med alt, hvad du kan finde på en standard-losseplads, men alle tingene er nye og rene, og de hænger fra loftet i hver sin snor. Nysgerrighed. Ovre på væggen er der en masse små hjul med hver deres tekst. Når du drejer på hjulet

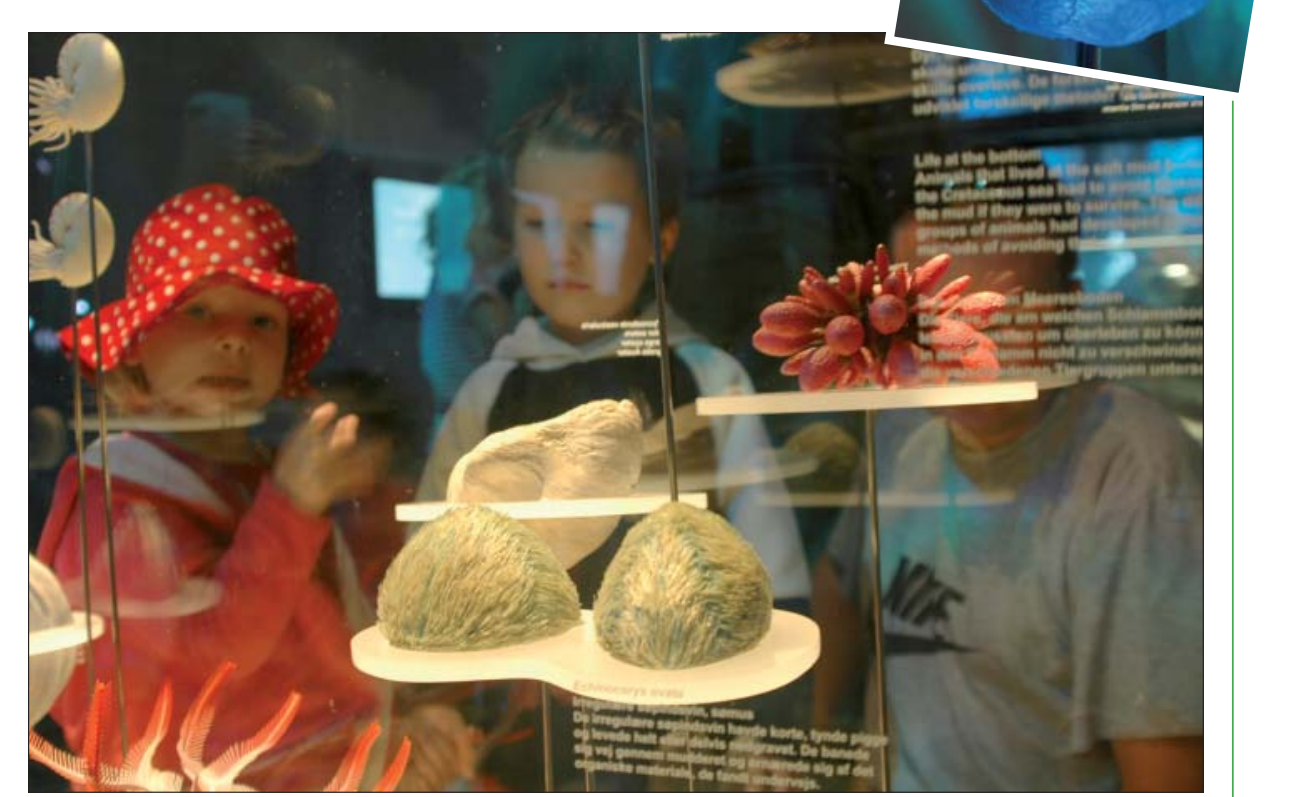

Der er mange spcendende ting at kigge på! (Foto: Forfatteren)

med teksten: "Ting der indeholder meget kalk”, hejser du tandpastatuben ned fra loftet. En plastic-tagrende indeholder tilsyneladende kun en lille smule kalk.

\section{Intet overflødigt isenkram}

Her er kortsagt et væld af oplysninger, som er blevet præsenteret så pædagogisk som muligt og uden hang til absolut at skulle bruge den nyeste og dyreste elektroniske dims. Klintens mudderskred bliver fint illustreret af en masse sand og en lille smule vand, så det hele glider langsomt og klistret ned. Men de elektroniske dimser er her så absolut, og det i store mængder, for de illustrerer fint, hvordan kokkolitskaller daler til bunds, og hvordan en mosasaurus jager.

Ifølge konceptet skal folk besøge centret, når de alligevel er ved klinten, og centret skal være overstået på tre kvarter. Men man skal også kunne fordybe sig i forskellige dele af det, og bruge den tid, man har lyst til. Det er absolut lykkedes, for vores nørderier startede efter cirka tre kvarter. Meget praktisk virker billetten en hel dag, så man kan se centret først, gå ned og se klinten og komme tilbage og undersøge sine egne fund. Så kan ungerne også lave amuletter af sten og træ fra turen.

\section{Engageret personale}

Centret er lige blevet færdigt, så der er stadig et par ting, der skal på plads, men personalets engagement kompenserer for manglerne. "Jeg bruger lige et par minutter på alle vores gæster”, forklarer Nils Natorp, som er direktør for centret, og som står i døren i dag. "Der mangler nemlig nogle skilte med aldre i udstillingen endnu, og uden dem er det ikke lige til at overskue det hele”. Bare halvdelen af juni har budt på 11.000 gæster.

\section{Prøv det}

Det nye center er absolut den yderste spids inde for læring og underholdning. Det er netop svaret på det, som får folk til at drage til Møns Klint: God gammeldags nysgerrighed. Her har vi et nyt fyrtårn for videnskab, som retter sig imod folk, der vil se klintens geologi og natur. En tæt pakket bus med formidlere er den mindste gestus, vi kan give dette nye center.

Og så lige en ting her til sidst. Når du kører ud fra centrets parkeringsplads, så scan parkeringsbilletten og kør helt frem til bommen. Den åbner nemlig ikke medens du scanner, men først når du er få centimeter fra den.

\section{Info}

Stengårdsvej 8, 4791 Borre • Tlf: 55863600 -geocenter@moensklint.dk

Mandag - søndag fra kl. 10.00 - 18.00. (31. oktober lukkes der for vinteren). 